\title{
PARTICIPAÇÃO, DEMOCRACIA E LIBERDADE CENTRADAS NA ECONOMIA SOLIDÁRIA. A EFICÁCIA DA NORMA TRABALHISTA NA IBEROAMÉRICA, A PARTIR DOS MOVIMENTOS SOCIAIS E DAS TEORIAS DOS MOVIMENTOS SOCIAIS
}

Everaldo Gaspar Lopes de Andrade

Professor Adjunto de Direito do Trabalho na Universidade Federal de Pernambuco e na Universidade Maurício de Nassau/PE. Professor da ESMATRA VI Região. Doutor em Direito pela Universidade de Deusto/ES.

Isabele Bandeira de Moraes D`Angelo Professora Assistente de Direito do Trabalho da UPE - Universidade de Pernambuco. Professora da Universidade Mauricio de Nassau e da Faculdade Damas. Doutoranda em Direito. Mestre em Direito.

\section{Resumo}

O tema eficácia da norma trabalhista no espaço embora apareça dentre aqueles que integram os fundamentos do Direito do Trabalho ou a sua Teoria Geral, os doutrinadores clássicos não lhes dá a devida atenção. Mesmo assim, quando a ele se refere, embora incluído naquela dimensão de importância, o fazem para retratar qual a norma a ser aplicada ao trabalhador contratado para prestar serviços fora do país; ou para aqueles que foram transferidos em caráter provisório ou definitivo e, finalmente, para dirimir conflitos envolvendo categorias profissionais específicas. Este estudo pretende dar um tratamento analítico e categorial à eficácia da norma trabalhista no espaço, na medida em que o destaca como um tema vinculado ao discurso filosófico da modernidade, à universalização/legitimação do trabalho livre/subordinado e a recepção desta a priori pelas chamadas organizaçóes e cooperaçôes internacionais, bem como pelas normativas ditadas pelo União Europeia e o Mercosul. O estudo se propóe a estabelecer uma narrativa diferente: colocar frente a frente a regulamentaçáo normativo/coercitiva e os absolutos universais decorrentes do sistema jurídico-trabalhista moderno e os movimentos sociais de raiz libertária que serão desencadeados pelo novo internacionalismo operário. Objetiva desvendar a aparente harmonia entre capital e trabalho e demonstrar o intrínseco e inerente antagonismo de classe. Os movimentos sociais e as teorias dos movimentos sociais formarão as bases desta reconfiguração teórico-dogmática, no sentido de privilegiar a Economia Solidária na Iberoamérica. 


\section{Palavras-chave}

Eficácia; universalização; Legitimação; Ideologia; Teorias dos movimentos sociais; Organizaçóes internacionais.

\section{Resume}

The theme effectiveness of labor standard in space even though it appears from those that make up the foundations of the Labour Law or his General Theory, classical scholars do not give them due attention. Still, when he refers, but included in that dimension of importance, they do to portray which standard to apply to the hired worker to provide services outside the country; or those who were transferred provisionally or permanently, and ultimately to resolve conflicts involving specific professional categories. This study aims to give an analytical and categorical treatment to the effectiveness of labor standards in space, to the extent that out as a theme linked to the philosophical discourse of modernity, the universal / legitimation of free / paid employment and receipt of this in advance by calling organizations and international cooperation, as well as the regulations dictated by the European Union and Mercosur. The study aims to establish a different narrative: put face to face the normative regulation / enforcement and universal absolute arising from modern legal-labor system and social movements of libertarian roots that will be triggered by the new labor internationalism. Aims to unravel the apparent harmony between capital and labor and demonstrate the intrinsic and inherent class antagonism. Social movements and theories of social movements form the basis of this theoretical-dogmatic reconfiguration, in order to privilege the Solidarity Economy in Iberoamerica.

\section{Key words}

Effectiveness; Universalization; Legitimation; Ideology; Theories of social movements; International organizations.

\section{Introdução}

O Estudo pretende abordar o tema Participação, Democracia e Liberdade na Ibero -América, a partir da Norma Jurídico-Trabalhista no Espaço, dos Movimentos Sociais e das Teorias dos Movimentos Sociais.

Parte, inicialmente, para questionar a doutrina jurídico-trabalhista clássica que negligencia quando trata da Eficácia da Norma Trabalhista no Espaço. Impressiona porque ela se insere dentre os estudos relacionados à Teoria Geral do Direito do Trabalho ou à Teoria do Conhecimento Jurídico Trabalhista.

Além de resumidos, ambíguos e lacunosos, os textos disponibilizados, especialmente aqueles que integram os manuais, se restringem às controvérsias oriundas das aplicaçóes 
das normas internas destinadas à proteção e ao regramento das relaçóes de trabalho envolvendo profissionais que são contratados no Brasil para trabalhar noutro país; ou são transferidos de maneira definitiva ou provisória. Envolvem, ainda que excepcionalmente, outras controvérsias resultantes das relaçóes de estrangeiros que trabalham no Brasil, especialmente aqueles que trabalham em consulados e representaçóes diplomáticas, consulares, etc.

Seguindo a proposição analítica ou categorial que inspirou trabalhos e livros publicados que seguem a teoria social crítica, os autores procurarão demonstrar a importância da ampliação da pauta hermenêutica tradicional, no sentido de revelar as motivaçóes legislativas e ideológicas que levaram o Estado Moderno, as Organizaçóes Internacionais, a União Europeia a vincular os sentidos da proteçáo social ao trabalho - contraditoriamente livre e subordinado, a manter uma postura ambígua a respeito das verdadeiras funçóes do sindicalismo, na medida em que se omitem e rejeitam a função emancipatória e contra -hegemônica dos movimentos coletivos organizados.

Esta a razão pela qual começa colocando em relevo o triunfo global do capitalismo, a fim de localizar a universalização das relaçóes sociais de produção e do conjunto das relaçóes sociais. Estes fenômenos desencadearam o aparecimento do sujeito de direito na sociedade moderna. Para compreendê-lo, faz-se uma análise dos argumentos lançados por Celso Naoto Kashiura sobre o sujeito de direito em Kant, Hegel e Marx.

Aprofundando os sentidos do trabalho na sociedade moderna, registra também o discurso filosófico da modernidade, no contexto da regulamentação normativo-coercitiva da ética moderna que, na visão de Zygmunt Bauman, estabelece uma aliança entre os legisladores e os pensadores modernos, pensamento ético que, aliado à moderna prática legislativa, buscarem abrir as possibilidades para uma solução radical, a partir das bandeiras gêmeas: universalidade e fundamentação. A aliança entre a prática dos legisladores e a universalidade significou a construção de um domínio, a partir de um conjunto de leis escritas instituídas num determinado território, no qual se estendia a sua soberania.

Este foi exatamente o caminho seguido pelo trabalho livre/subordinado que se universalizou enquanto objeto do Direito do Trabalho, espalhou-se, para integrar os sistemas jurídicos do Estado Moderno, mas, agora, entre em crise, inclusive na Ibero-América..

Fenômeno explicável também pelo binômio ideologia/hegemonia, na medida em que a evangelização, a glorificação e a legitimação/universalização do trabalho livre/subornado se instituíram como forma política da existência, por meio das ideologias e no conjunto dessas práticas sociais, em que o comando empregatício patronal se torna um poder. Os empregados, como os súditos na política, autorizaram um consentimento "livre" e consuetudinário, a recepcionaram os sentidos da obediência. 
Um sistema contraditório que, segundo Gramsci, aponta para os Aparelhos Ideológicos do Estado - um conjunto de instituiçóes ideológicas, religiosas, morais, jurídicas, políticas e estéticas, dentre outras. Aqui, o estudo se vale da interpretação dada por Enoque Feitosa, a partir de Althusser, Marx e Gramsci para demonstrar esta transubstanciação - de trabalho sacrifício, vendido comprado, para trabalho evangelizado, glorificado, centro de referência da sociabilidade.

A leitura das relaçóes internacionais, corolário da eficácia da norma trabalhista no espaço, só faz sentido quando se tem, como ponto de partida, ou seja, quando se estabelecer um confronto entre a universalização/legitimação do trabalho subordinado como objeto do Direito do Trabalho - centro de referência para as Organizações e as Cooperaçôes Internacionais, das normas comunitárias - e as possibilidades de uma outra universalização/legitimação decorrente de um novo internacionalismo operário, que privilegie as lutas emancipatórias a serem deflagradas simultaneamente nos espaços locais, regionais e supranacionais.

Por meio de um embate entre estas duas alternativas de universalização/legitimação dos direitos sociais, o estudo vislumbra a possibilidade de reconfiguração teórico-dogmática da eficácia da norma trabalhista no espaço e sua importância rumo a modelos de relaçóes de trabalho participativos, democráticos e libertários no âmbito da Iberoamérica. Sobretudo, com a prevalência da Economia Social e Solidária.

\section{0 Triunfo Global do Capitalismo. A Universalização das Relações Sociais de Produção e do Conjunto das Relações Sociais}

Marx e Engels (2012), já em 1848, registraram o caráter historicamente revolucionário desempenhado pela burguesia. Por isso, sempre que ela assumiu o poder, "destruiu todas as relaçôes feudais, patriarcais, idílicas. Estilhaçou, sem piedade, os variegados laços feudais que subordinavam o homem a seus superiores naturais" (2012, p. 27).

O mais notável desta previsão, ideologia à parte, é que eles também sabiam que a burguesia não poderia existir sem revolucionar sempre os instrumentos de produção; "portanto, as relaçôes de produção; e assim o conjunto das relaçôes sociais" (Idem, 28). Admitiram, ainda, que "pela exploraçáo do mercado mundial, a burguesia tornou cosmopolita a produção e o consumo de todos os países" (Idem, p. 29). Deixaram, por fim, uma constatação que se tornaria inexorável para que possamos compreender não só aquele caráter revolucionário, mas, como ele se mantém por meio daquilo que chamaram de rápido desenvolvimento de todos os instrumentos de produção - infinitamente facilitados pelas comunicações. Assim,

em apenas um século de sua dominação de classe, a burguesia criou forças de produção mais imponentes e mais colossais que todas as geraçôes 
precedentes. O domínio das forças naturais, o maquinismo, as aplicações da química à indústria e à agricultura, a navegação a vapor, as ferrovias, o telégrafo, o desbravamento de continentes inteiros, a canalização de rios, o aparecimento súbito de populações - que século anterior se poderia prever que tais forças produtivas cochilavam no seio do trabalho social?

Segundo Leo Huberman (1986) "o crescimento da população, as revoluçóes nos transportes, agricultura e indústria - tudo isso estava correlacionado. Agiam e reagiam mutuamente. Eram forças abrindo um mundo novo" (Idem, p. 174). Por isso, conforme anuncia Eric J. Hobsbawm (2009, p. 21), “o triunfo global do capitalismo é o tema mais importante da História nas décadas que se sucederam a 1848", uma vez que "na década de 1860, uma nova palavra entrou no vocábulo econômico e político do mundo: o capitalismo" (Ibidem, p. 21).

Um estudo contextualizado sobre o Direito do Trabalho deve considerar o momento histórico em que se deu esta revolução, ou como diria Koselleck (1999, p. 10), que o "século XVIII É a antecâmara da época atual, cuja tensão se acentuou progressivamente deste a Revolução Francesa, que afetou o mundo inteiro, extensivamente, e todos os homens intensivamente.”. A função política que surge no seio do pensamento e nas aspirações da burguesia, aliado ao papel que eles desempenharam no âmbito do Estado Absolutista foram capazes de elaborar um significado político para o Iluminismo que forçou a necessidade de se "indagar sobre a estrutura da primeira vítima da Grande Revolução, o Estado Absolutista, cujo desaparecimento possibilitou o desdobramento da modernidade utópica" (Ibidem, p. 11).

A estrutura do poder econômico e do poder político já consolidado nas últimas décadas do século dezenove foi desenhada também pelos anarquistas. Nos textos produzidos entre 1880 e 1882, Kropotkin (2005) afirma:

Ou, então este capital irá construir ferrovias inúteis, no Gotardo, no Japão, no Saara, se preciso for - desde que os Rothschild fundadores, o engenheiro-chefe e o empreiteiro ganhem, cada um alguns milhôes.

Sobretudo, porém, o capital se lançará na agiotagem: o grande jogo da Bolsa. O capitalista especulará com a alta factícia dos preços do trigo ou do algodão; especulará com a política, com a alta que se produzirá, em consequência de tal boato de reforma ou de certa nota diplomática; e, muito a miúde, serão - isto se vê todos dos dias - os próprios corretores do Governo, que participarão destas especulaçóes (Idem, p. 24).

Sem pretender entrar na peleja sobre uma reinterpretação categorial do marxismo, entendemos que faz sentido o argumento lançado por Moishe Postone (2014) de que uma crítica do capitalismo não pode ficar condicionada a uma noção trans-histórica de "trabalho". Assim, o trabalho tem que ser visto como possuidor de um caráter socialmente 
determinado e específico da formação social capitalista. Analisaremos essa qualidade específica elucidando a concepção de Marx do "duplo caráter" do trabalho no capitalismo. Sobre essa base poder-se-á determinar adequadamente valor como uma forma historicamente específica de riqueza e de relaçóes sociais e mostrar que o processo de produçáo incorpora tanta as "forças" quanto às "relaçôes" de produção, e não se limita a corporificar somente as forças de produção.

Vamos fazê-lo demonstrando que, de acordo com a análise de Marx, o modo de produzir no capitalismo não é simplesmente um processo técnico, é, na verdade, moldado pelas formas objetivadas das relaçóes sociais (valor, capital). Daí se torna claro que a crítica marxiana é uma crítica do trabalho no capitalismo, não apenas uma crítica da exploraçáo do trabalho e do modo de distribuição, e que a contradição fundamental da totalidade capitalista deve ser vista como intrínseca ao reino da produção em si, e não apenas uma contradição entre as esferas de produção e distribuição (Idem, p. 148).

\section{O Sujeito de Direito. Sua Tríplice Compreensão - Kant, Hegel e Marx - Segundo Celso Naoto Kashiura}

Um problema chave que envolve a teoria do direito remete, de início, como defende Celso Naoto Kashiura (2014) à compreensão do tema sujeito de direito. Para ele, a partir de uma tríplice compreensão - em Kant, Hegel e Marx. Em Kant, no sentido de entender o "segredo" da universalidade do imperativo categórico que reside na forma, ou seja, da forma da reciprocidade universal, que aparece simultaneamente subjetiva - por estar centrada no indivíduo e na ação indivíduo - e objetiva, por ser válida universalmente. Assim,

A universalidade, como forma, e o fim em si mesmo do ser racional, como matéria, implicam um modo de determinaçáo peculiar da própria vontade do sujeito que se conforma ao dever objetivo. Pois, segundo Kant, não se pode conceber que o imperativo categórico determine a vontade do sujeito como algo que lhe é exterior. O imperativo categórico só pode emanar da mesma vontade que, como vontade de um ser racional, ao concordar com ele, concorda táo somente consigo própria. A vontade do sujeito, isto é, a vontade de todo e qualquer ser racional, há de ser então considerada simultaneamente como vontade legisladora universal. "A vontade - diz Kant - não está simplesmente submetida à lei, mas sim submetida de tal maneira que tem que ser considerada também como legisladora ela mesma, e exatamente por isso e só submetida à lei ( de que ela se pode olhar como autora)". Kant pode, entấo, falar coerentemente numa "livre sujeição": a submissão da vontade à razão é submissão da vontade a si mesma, isto é, do sujeito a si mesmo e, portanto, de um sujeito que permanece livre ainda quando - ou melhor, exatamente quando - submetido à necessidade da açấo formalmente conforme ao comanda da razão (Idem, p. 30). 
Imperativo categórico que se desdobra em princípios que estão já nele implicados e apresentados sob três diferentes formulaçôes: "princípios práticos da moral; universalidade quanto á forma; o ser racional como fim em si mesmo, quanto à matéria; vontade racional como legisladora universal, no que diz respeito à determinação” (Idem, p. 31).

Já o direito abstrato e a universalidade da vontade livre se instituem, na filosofia do direito de Hegel, na medida em que se concebe o direito enquanto forma, "que a forma direito é determinada pela forma sujeito de direito, e que a forma sujeito de é necessariamente universal" (Idem, p. 89). Ao contrário da Metafísica dos costumes de Kant, a categoria sujeito de direito está presente e definida, sendo que o primeiro desdobramento que vai derivar-se do sujeito de direito é a propriedade - a primeira determinação da pessoa, da qual resulta o pressuposto capacidade jurídica, contida na personalidade jurídica que, por seu turno, "apresenta-se logo como a capacidade de ser proprietário"(Idem, p. 95).

Em Marx as versóes - idealista e humanista - desta categoria jurídica sujeito de direito é problematizada e refutada, na medida em que são postas para dentro da própria dinâmica da formaçáo social concreta; conduzida para o contrastante movimento histórico das relaçóes de produção e, diante da estrutura de uma forma histórica de sociedade, as palavras de ordem - liberdade, igualdade, personalidade jurídica típicas do indivíduo isolado e do voluntarismo jurídico - se desvanecem.

Não seria mais na suposta "natureza humana” ou no "espírito" em seu progresso, "mas nas profundezas do modo de produção capitalista é agora encontrada a determinação real do portador abstrato de direitos e deveres, as raízes da forma sujeito de direito" (Idem, p. 159).

Resumindo a abordagem sobre o sujeito de direito em Kashiura Jr, podemos considerar, segundo as suas próprias palavras, o seguinte:

a) Em Kant, pudemos destacar o delineamento de uma filosofia moral cujo fundamento é a universalidade de um sujeito moral autônomo e, portanto, cuja base real última é a circulação mercantil e a forma atômica do indivíduo isolado proprietário de mercadorias. Ao mesmo tempo, pudemos encontrar no pensamento kantiano propriamente jurídico, que é diretamente derivado dessa filosofia moral, uma figura que implica o sacrifício de uma universalidade do sujeito de direito, o ius realiter personale, meio-termo entre direito pessoal e direito real, segundo a esposa, os filhos e os criados domésticos podem ser possuídos como se fossem coisas pelo senhor da casa (pai e marido)... Contradição que pode ser explicada como uma tentativa, por parte de Kant, de "racionalizar” relaçóes sociais ainda residualmente pré-burguesas. (Idem, p. 242)

b) Procuramos, nesse sentido, mostrar que Hegel eleva o sujeito de direito à condição de pleno proprietário de si mesmo, e que essa propriedade tem, como 
todas as demais, o caráter de "coisa exterior", de modo que, ao dispor dessa "coisa exterior", o sujeito de direito realiza a vontade livre "interior" intangível que o constitui. A coisificação "exterior" não apenas não viola a vontade "interior", mas se realiza nela e por meio dela. Hegel assim resolve as exigências fundamentais que, por debaixo da circulação, a produção capitalista lança: a constituição do homem como sujeito de direito para que a força de trabalho circule livremente como mercadoria. A produção, no entanto, jamais aparece como tal - e a concepção hegeliana de sociedade civil, sobretudo com o sistema dos carecimentos e as desigualdades que lhe intrínsecas, é a cabal prova disto. (Idem, 243)

c) Por fim, ao voltar a Marx, pudemos mostrar inicialmente a íntima proximidade entre o sujeito de direito e mercadoria, essas "duas formas absurdas" de sociedade burguesa. Pudemos encontrar, seguindo a via aberta por Pachukanis, a determinaçáo imediata da forma sujeito de direito no processo de troca de mercadorias. Mas ainda, pudemos mostrar, a partir de Márcio Bilharinho Naves, a determinação em última instância do sujeito de direito pela produção especificamente capitalista, que, com a subsunção real do trabalho ao capital, realiza a abstração constitutiva da equivalência subjetiva jurídica... E tendo fixado o sujeito de direito como forma social especificamente capitalista, foi possível reafirmar a exigência incontornável de extinção da forma jurídica em conjunto com a extinção do modo de produção capitalista. (Idem, p. 243)

\section{O Discurso Filosófico da Modernidade. A Regulamentação Normativo-Co- ercitiva e os Absolutos Universais da Ética Moderna. A Visão de Zygmunt Bauman}

Para Zygmunt Bauman (1997), a marca da ética moderna consiste nas tentativas de tratar os problemas morais ou responder aos desafios morais, tendo como pressuposto a regulamentação normativa coercitiva, ou seja, a busca filosófica de absolutos universais e fundamentaçóes centradas na teoria. A moral, enquanto aspecto de pensar, sentir e agir do gênero humano, no tocante à discriminação entre o "certo" e o "errado", foi uma construção da idade moderna.

É que, na maior parte da história, havia pouca diferença entre os padróes da conduta humana, tal como hoje se estabelece, em termos de diferença que se passou a fazer na modernidade, quando o tema se dirige à conduta humana e suas distinçóes - utilidade, verdade, beleza, propriedade.

Parte do princípio segundo o qual, se, na modernidade, as pessoas adquiriram mentalidade individualista, já que passam a interessar-se egocentricamente só por si mesmas, 
na medida em que ficaram sem Deus e perderam a fé nos dogmas religiosos; se o desenvolvimento moderno forçara os homens e as mulheres à condição de indivíduos, com suas vidas fragmentadas, separadas em muitas metas e funçôes soltamente relacionadas - cada uma a ser buscada em contextos diferentes e segundo pragmática diversa - era preciso construir uma visão unitária do mundo e substituir a diversidade pela uniformidade, a ambivalência pela ordem coerente e transparente.

A questão sendo colocada desta maneira: apesar de as condiçóes existenciais do gênero humano na vida moderna terem sofrido alteraçóes, a velha pressuposiçáo de que a vontade livre se expressa apenas em escolhas erradas, bem como a compreensão de a liberdade, quando não monitorada, resvalar para a licenciosidade e, sendo assim, tornar-se inimiga do bem, continuou a dominar as mentes dos filósofos e as práticas dos legisladores. E tudo isso era visto "desde o alto", pelos responsáveis, pelo "curso da sociedade", pelos guardas do "bem comum”. Se a liberdade do indivíduo é suspeita, desde o início, pela imprevisibilidade de suas consequências e fonte constante de instabilidade, deveria preocupar aqueles observadores, por ser, também, elemento do caos. Liberdade que deveria ser freada, para assegurar e manter a ordem.

Não foi por acaso que o moderno pensamento ético, aliado à moderna prática legislativa, buscou abrir as possibilidades para uma solução radical, a partir das bandeiras gêmeas: universalidade e fundamentação. A aliança entre a prática dos legisladores e a universalidade significou, sem exceção, a construção de um domínio, a partir de um conjunto de leis escritas num determinado território, no qual se estendia a sua soberania.

Por outro lado, os filósofos cuidaram de definir a universalidade, no contexto de um traço inserido nas prescriçóes éticas que envolviam e compeliam toda criatura humana àquela universalidade. Se, de um lado, a universalidade, na prática dos legisladores, aparecia como domínio, sem exceção, do aparato legislativo elaborado para viger num determinado território em que se estabelecia a sua soberania; aos filósofos cabia definir a universalidade como aquele traço das prescriçóes éticas que, por seu turno, compelia toda criatura humana. Só pelo fato de ser criatura humana deveria reconhecê-lo como direito e a aceitá-lo como obrigatório.

Para ele, Jeremy Bentham, ao se manter fiel à inspiração de Hobbes, tornou-se o maior responsável pela agenda da moderna filosofia ética. Como os seres humanos têm deficiência de altruísmo, teriam eles necessidade da ameaça da coerção para serem encorajados a buscar os interesses da maioria. Portanto, as intençóes e os atos morais somente poderiam ser concretizados por meio da engenharia social. E os engenheiros convocados para executar a tarefa seriam de duas espécies: a) os legisladores, que se encarregavam de produzir e sancionar as leis do país, com o objetivo de coibir aqueles que tentarem buscar egoisticamente a felicidade e consideram a felicidade dos que os cercam; b) os pensadores morais, a quem caberia uma dupla tarefa: de um lado, aconselhar os legisladores, 
indicando-lhes a maneira como deveria ser socialmente manipulada a distribuição social dos prazeres e das dores. O objetivo era tornar mais provável a submissão. A segunda tarefa se voltaria para convencer os coagidos "de que eles fazem justiça a seu impulso de busca de felicidade se sujeitarem à coerção sem resistir" (Idem, p. 78).

A relação de emprego que se universalizou e se legitimou, com objeto do Direito do Trabalho, não é aquela centrada num tipo de coação subjacente, que existe em potência? Que decorre da subordinação da força do trabalho ao capital? Que está centrada no poder disciplinar de um dos sujeitos desta relação - o empregador?

\section{A Filosofia - Ciência das Condições a Priori. Ideologia, Hegemonia e "Su- peração" das Contradições. Althusser, Marx e Gramsci, segundo Enoque Feitosa}

Conforme esclarece Louis Althusser (1989), a filosofia pretende ser considerada como a ciência das ciências e se apresentar como a ciência das condiçóes a priori de qualquer ciência e, como tal, pretende exercer poder sobre elas. Ao incorporar todas as práticas sociais e as ideias sociais no domínio do seu pensamento, para impor-se ela mesma sobre essas práticas e ideias, tem como objetivo dizer-lhes a sua verdade. Para isso, precisa absorvê-las e reelaborá-las com a sua própria forma filosófica. Ao apresentar-se como ciências das ciências ou como ciência das condiçôes a priori, ao afirmar seu poder de verdade sobre as práticas e ideias sociais, as obriga a sofrer uma verdadeira transformação, muito embora essa Verdade costume ser imperceptível. Por isso, "na medida em que ou observa o todo ou pensa o todo, empurra o espaço exterior para dentro dela" (Idem, p. 29).

Aqui reside a forma política da existência das ideologias no conjunto dessas práticas sociais, em que o conceito de ideologia dominante se institui da seguinte maneira: na sociedade dividida em classes, o poder político encontra-se nas mãos da classe dominante. Mas, essa mesma classe dominante, para tornar o poder duradouro, necessita fazer com que o poder, pela violência, se transforme em poder político consentido. Para conseguir esse objetivo ela precisa, ainda, obter dos seus súditos, mediante um consentimento livre e consuetudinário, a sua obediência. Obediência que não pode ser conseguida, apenas, pela força. Este sistema contraditório aponta, segundo Gramsci, para os Aparelhos Ideológicos do Estado, caracterizados por um conjunto de instituições ideológicas, religiosas, morais, jurídicas, políticas e estéticas, dentre outras.

A partir desse conjunto de instituiçôes, essa forma política de existência se unifica, para impor às massas exploradas a sua ideologia peculiar exatamente para que as massas a incorporem como sua própria ideologia. A ideologia que se constitui e ainda supera essas contradiçóes quando aparece unificada em torno dos interesses essenciais dessa mesma classe dominante, sobretudo para assegurar a sua hegemonia, no sentido também gramsciano do termo. 
Seguindo ainda o rastro de Marx, admite que uma determinada formação social encontra-se lastreada na sua infraestrutura econômica, ou seja, sobre a unidade de forças produtivas e nas relaçôes de produção, mas, na infraestrutura está também enraizada a luta de classes - resultante do confronto entre os possuidores dos meios de produção e os trabalhadores mais diretamente explorados. Reforça o argumento segundo o qual, sobre essa infraestrutura, se edifica uma superestrutura - Estado e Direito, por um lado, e as ideologias, por outro - que faz a formação social reproduzir-se e reproduzir as suas próprias condições de existência - condiçôes econômicas e políticas de reprodução legitimadas pelo Direito e pelo Estado.

As ideologias - jurídica, política, moral, religiosa, filosófica -, quando participam das relaçóes de produção no conjunto das relaçóes sociais, servem para assegurar a hegemonia e o ideal ou a cultura da classe dominante. Para ele, o conjunto das ideologias recebe da filosofia, sob as categorias de Verdade, essa unidade e a sua orientação, ou seja, a forma política da existência das ideologias, no conjunto das práticas sociais.

Unificar as ideologias em torno de uma ideologia dominante e conferir a esta o seu poder de verdade, a fim de reduzir as contradiçóes e unificar as práticas sociais, corresponde a um "trabalho abstrato, de um trabalho de pensamento, trata-se de um pensamento puro, de uma teorização pura, a priori, portanto" (Idem, p. 48).

Afirma Enoque Feitosa (2012, p. 107-157) que o direito, como ramo específico do saber voltado para a regulação das relações sociais, somente poderá ser compreendido em sua plenitude, quando se utiliza de um método que "o insira como parte de uma totalidade histórica específica - a sociabilidade cindida -, isto é, aquela que é produto de uma formação social na qual a força de trabalho é apenas uma mercadoria” (Idem, p. 108). Numa sociedade estruturada dessa maneira, o direito cumpre um papel específico "de tecnologia social para lidar com conflitos resultantes dessas mesmas relaçóes" (Idem, p. 108).

A partir das ferramentas disponibilizadas pelo método desenvolvido por Marx, é possível estabelecer uma interpretação histórico-social para o direito e, assim, inverter as perspectivas, para aquelas que "tentam explicar a sociedade pelo direito (e não o oposto), como se a forma jurídica fosse uma espécie de deus ex machina" (Idem, p. 108). A "visáo jurídica do mundo", sucedâneo da "concepção teológica do mundo", torna-se um fenômeno tipicamente moderno, em que a chamada "consciência jurídica" cumpre um papel chave na sociedade burguesa e que tem, por outro lado, uma missão, um objetivo: efetivar o controle social.

O direito é assim compreendido enquanto representação cotidiana de um fenômeno ambivalente - infraestrutural e, simultaneamente, superestrutural. Reflete determinadas concepçóes sociais, pois rebate, no mundo das ideias, a luta concreta que se estabelece na infraestrutura das relaçóes sociais, ao mesmo tempo em que interfere e cria realidades 
sociais. Os conflitos não superáveis - que decorrem do quadro de desigualdades e que, por seu turno, exigem uma solução controlada desses mesmos conflitos, por intermédio do Estado - tornam-se a razáo de ser ou de existir do próprio direito.

E a ideologia/hegemonia não se instituiu, na Sociedade Moderna, no Estado Liberal, quando a categoria chave da sociabilidade passou a ser o trabalho livre/subordinado; quando ideologicamente ele se transfigurou - deixou de aparecer como sinônimo de sacrifício, dor e passou a ser glorificado, evangelizado?

\section{A Regulamentação Normativo-Coercitiva e os Absolutos Universais que Instituíram o Trabalho Livre/Subordinado como Objeto do Direito do Tra- balho}

Os autores deste trabalho ${ }^{1}$ vêm insistindo na ideia segundo a qual o trabalho contraditoriamente livre/subordinado adquiriu o status de objeto do Direito do Trabalho, de a priori de suas teorizaçóes, com o advento da modernidade. Foi exatamente neste ambiente político, econômico e social que o trabalho abstrato foi uniformizado, universalizado e recepcionado pela teoria jurídico-trabalhista e seu corpo de doutrinas. Esta uniformização/universalização legitimou o aparecimento de uma legislação específica destinada a disciplinar um tipo de relaçáo jurídica especial - a do trabalho livre/subordinado/ assalariado - e a resolver os seus conflitos.

Temos, ainda, lançado ideia de que o trabalho livre/subordinado/assalariado, que passou, a partir daquele momento histórico, a ser considerado o ethos fundamental da convivência das pessoas em sociedade e a priori das teorizaçóes para diversos ramos das chamadas ciências sociais, não pode mais considerar-se objeto deste campo do conhecimento jurídico, porque se encontra refutado, por meio das evidências empíricas e analíticas presentes nos estudos avançados desenvolvidos pela teoria social crítica de vários matizes.

Temos ainda, deixado sempre as seguintes indagaçóes: por que, diante de tantas alternativas de trabalho e de tantas opçóes teóricas e filosóficas que desqualificam aquela opção, foi exatamente esta que se uniformizou, se universalizou e possibilitou a construção de um sistema normativo-coercitivo especifico que até hoje perdura? Por que, diante das evidências empíricas que constatam as metamorfoses que atingem as relaçóes de trabalho contemporâneas - trabalho precário, clandestino, terceirizado, subcontratado que

1 D’ANGELO, Isabele de Moraes. A Subordinaçấo no Direito do Trabalho.Para ampliar os cânones da proteção, a partir da Economia Social e Solidária. São Paulo: LTr, 2013; ANDRADE, Everaldo Gaspar Lopes de. O Direito do Trabalho na Filosofia e na Teoria Social Crítica. Os sentidos do trabalho subordinado na cultura e no poder das organizaçóes. São Paulo: LTr, 2014. 
convivem, ainda, como o desemprego estrutural, manter aquela alternativa de trabalho, hoje minoria, no contexto da população economicamente ativa?

Os juristas tradicionais continuam reproduzindo o mesmo argumento que conduziu o Direito do Trabalho a um ramo especial do conhecimento jurídico, ou seja: antigamente, havia trabalho escravo/servil; agora, trabalho livre/subordinado/assalariado.

A partir da glorificação, da evangelização desta modalidade de trabalho, afirma que este ramo do direito promoveu uma verdadeira revoluçáo no campo do Direito Privado - especificamente, na esfera da autonomia da vontade. Na medida em que, ao contrário do Direito Privado - centrado na liberdade e na igualdade das partes, reconhece haver uma assimetria entre os sujeitos, no âmbito daquela relação jurídica especial - capital e trabalho, empregador e empregado - o Direito do Trabalho passou a erigir fundamentos capazes de conceder superioridade jurídica àquele que aparece, neste âmbito contratual - o empregado -na condição de inferioridade econômica - em relação à outra parte - o empregador. Daí foi possível elaborar um dos seus princípios nucleares: o Princípio da Proteção.

Apesar destas premissas, fica outra indagação: o Direito do Trabalho e seus fundamentos desencadearam realmente uma revolução no campo do Direito Privado ou foi ele próprio indispensável para legitimar os modelos de estado e de sociedade que surgiram após a queda do Absolutismo Monárquico - em que os poderes se encontravam nas mãos do clero e da nobreza, e permitir a ascensão da burguesia nascente ao poder e dar origem ao Estado Liberal - centrado no individualismo contratualista, na supremacia do trabalho vendido, comprado, separado da vida e no racionalismo instrumental a serviço da produção capitalista?

Esta mesma doutrina majoritária não consegue superar esta contradição, pois ela se encontra no centro de seus próprios argumentos: como eliminar a assimetria, a desigualdade entre aqueles dois sujeitos - empregador e empregado -, quando, de um lado, encontra-se aquele que admite, assalaria, dirige e disciplina a prestação pessoal de serviços - o empregador - e, do outro, aquele que fica jurídica, econômica e psicologicamente subordinado ao empregador - o empregado? Como eliminá-la se, em virtude dessa desigualdade, aparece uma coaçáo - jurídica, econômica e psicológica - subjacente e que existe em potência?

Compreender a supremacia do trabalho vendido, comprado separado da vida como centro de referência da sociabilidade, significa reconhecer, de saída, o triunfo global do capitalismo e a universalização das relaçôes sociais de produção dele decorrentes; significa reconhecer um sujeito de direito que foi imaginado para se envolver nesta trama; significa que a aliança entre os filósofos e os juristas modernos tratou de conceber uma regulamentação normativo-coercitiva e seus absolutos universais dirigidos à legitimação 
da sociedade do trabalho centrada no trabalho contraditoriamente livre/subordinado; que esta legitimação somente poderia se instituir e se consolidar, na medida em que a filosofia assumisse a sua condição de a priori de qualquer ciência; quando a ética moderna procurasse dar respostas aos desafios morais, a partir, repita-se, de uma regulamentação normativo-coercitiva e de absolutos universais.

Esta regulamentação normativo-coercitiva centrada em absolutos universais legitimou o aparecimento de um tipo de sujeito de direito universalizado. Por isso, assevera Jorge Luiz Souto Maior (2011) que o capitalismo é um sistema pelo qual a sociedade de classes "se organiza polarizada em uma classe que ostenta o capital, e uma classe trabalhadora, que vem sua força de trabalho para satisfação dos interesses econômicos da classe dominante." (Idem, p. 554). Para Reginaldo Melhado (2003):

O contrato de emprego, na sua gênese arquetípica, é um contrato de compre e venda - através do qual o trabalhador aliena sua capacidade de trabalho como mercadoria - caracterizado um elemento subjetivo específico: a intencionalidade da conduta do capitalista, que adquire a mercadoria força de trabalho para destiná-la à ampliaçáo do capital, que por seu turno não é outra coisa senão trabalho objetivado... Contrapartida da alienação mercantil da força de trabalho, o salário é produzido pelo próprio trabalhador, pois ele quem produz todas as riquezas (Idem, p. 215).

\section{A Eficácia da Norma Trabalhista no Espaço. Uma Visão Crítico-Prospectiva}

Aqueles que, no âmbito do Direito do Trabalho, seguem o rastro da teoria social crítica também já evidenciaram a necessidade de colocar em relevo as relações sindicais - abstratas - diante da prevalência das relaçóes individuais de trabalho, exatamente por tratar-se de um direito que surge da luta de classe. Mas, o fizeram articulando a doutrina jurídico-trabalhista crítica às teorias dos movimentos sociais e aos novos movimentos sociais.

Os autores deste trabalho compartilham desta versão analítica e deixam transparecer a sua oposição à correte doutrinária dominante que, seguindo a velha tradição, acredita na harmonia entre capital e trabalho.

No plano internacional, questionam as possibilidades de um consenso que possa resultar dos interesses proclamados simultaneamente pela Organização Internacional do Trabalho e a Organização Internacional do Comércio; na crença da humanização do trabalho, sem que seja superada a subordinação da força do trabalho ao capital; sem que os direitos sociais a serem construídos possam ir além do trabalho livre/subordinado; sem que finalmente a eficácia da norma trabalhista, para manter a sua universalidade, provenha de movimentos emancipatórios e contra-hegemônicos a serem desencadeados nos 
planos locais, regionais e supranacionais. Posição teórica que ainda tem relevância para a Iberoamérica, na medida que se apontará para um modelo de Sociedade do Trabalho centrado na Economia Social e Solidária.

\subsection{As Organizações Internacionais e as Utópicas Possibilidades de Cooperação Internacional}

Fica, portanto, esclarecido, de início que, do ponto da eficácia da norma trabalhista no espaço, os pressupostos teórico metodológicos não estão condicionados à hermenêutica - interpretação da lei interna às relaçóes de trabalho prestados no exterior, mas aos modos de produção normativa e aos discursos ideológicos que se instituem e se estabelecem por meio da organizaçóes internacionais, da cooperação internacional e que desencadeiam a formação de regras jurídicas e resolução de conflitos nas esferas locais, regionais e supraestatais.

No primeiro caso, tem-se, de um lado, a Organização Internacional do Trabalho e, do outro, a Organização Internacional do Comércio; no segundo, as regras jurídicas que provém do Parlamento Europeu e das disposiçóes normativas extraídas do MERCOSUL. Tais experiências, no entanto, ficam restritas à proteção reducionista do trabalho livre/ subordinado; e às possibilidades de atuação e de intervenção dos interlocutores sociais válidos, entendendo-se como tais as organizaçôes sindicais de raízes reformistas.

Do ponto de vista da teoria jurídico-trabalhista, há dois critérios definidores da aplicação da norma trabalhista no espaço. No primeiro caso, segue-se a orientação traçada pelo Direito Internacional Privado. Neste caso, prevalece a lei do local da execução do contrato - Código de Bustamante - adotada pelo Brasil e que portanto opta pelo princípio da territorialidade, na salvaguarda a soberania nacional. Com o advento da lei 7.064/82 algumas controvérsias continuaram, quando se tem, na experiência, trabalhadores brasileiros que prestam serviços às empresas brasileiras que executam empreendimentos noutros países com empregados transferidos ou já contratados para trabalhar no exterior; trabalhadores contratados por empresas estrangeiras para prestar serviços no exterior, etc.

No segundo caso, tem-se aquilo que Miguel Colina Robledo, Juan M. Ramírez Martínez e Tomas Sala Franco (1991) consideram, para o Direito Social Comunitário, como livre circulação dos trabalhadores assalariados. Deixam transparecer inclusive as dificuldades sofridas pelos trabalhadores que perdem o emprego, os trabalhadores fronteiriços, os trabalhadores de temporada, etc. (Idem, p 164).

Diante da complexidade das relaçóes de trabalho, das metamorfoses em curso; quando se olha para a própria história da organização operária, verifica-se que o capitalismo não surgiu para ser hegemônico num determinado país ou numa determinada região, veio para ser, como de fato o é, hegemônico no mundo. Diante dos avanços, sobretudo 
empreendidos pela tecnologia da informação e da comunicação, bem como aqueles trazidos pelas máquinas inteligentes, verifica-se que, antropologicamente, não é apenas o capitalismo que é nômade o trabalhador sedentário; este poderá ser também e, ao mesmo tempo, sedentário e nômade - neste último, para participar de um processo global de insurgência.

Examinando-se a questão por este prisma, verifica-se que a livre circulação de trabalhadores somente pode ser explicada historicamente por meio da dialética da colonização; a exploração, a discriminação e os distúrbios psicofísicos que atingem os trabalhadores imigrantes têm a ver com este mesmo domínio - agora comandado pelo ultraliberalismo global.

A professora Maria Clara Bernardes Pereira (2014) aponta para um rompimento com as novas faces do colonialismo e com os apartheids urbanos, na medida em que se pode reconhecer, no nomadismo operário contemporâneo, uma categoria integrante da nova morfologia do trabalho e das lutas emancipatórias.

Segundo Jérôme Bindé (2000), existe um novo espectro que assombra as cidades no limiar do século XXI, o apartheid urbano que aponta para modalidades de alojamento repartido por zonas de habitação e que distribui as pessoas segundo categorias de rendimento ou grupos e culturais.

Verifica-se claramente, nas grandes cidades ricas do mundo, o fosso entre bairros privilegiados e fechados sobre si mesmos e, do outro, os bairros onde ficam os imigrantes, as minorias étnicas, donde se pode constatar um verdadeiro dualismo, uma verdadeira segregação. Registra ainda uma vasta camada média que flutua entre estas duas categorias que também vive ameaçada de desqualificação social. Para a professora Clara Bernardes não é possível remover as barreiras discriminatórias que acompanham, ao longo da história, "a discriminação e a exploração do trabalho imigrante, sem se redefinir os sentidos do trabalho e redefinir também os sentidos do novo internacionalismo operário” (Idem, p. 121).

A professora Talita Rodrigues Mendonça, quando enfrenta o tema "O poder capitalista pós-industrial e nômade" (Idem, p. 87) e "os movimentos sociais globais contrários a exploração capitalista”, começa invocando o juslaboralista alemáo Wolfgang Däubler (1997), para dizer que a internacionalização da produção e do comércio encontrou a sua expressão maior na criação de grupos multinacionais e estes modificam também "as forças no confronto entre capital e trabalho"(DAUBLER, 1997, p. 89). Por isso, os trabalhadores têm "dificuldade em localizar concretamente o centro das decisóes, quanto mais em obter uma visão global de todas as atividades do grupo, inclusive a situação financeira” (DÄUBLER, 1997, p. 89).

Segue, na sua análise, também a trilha desenvolvida por Manuel Castells, para quem a sociedade está organizada em espaços de fluxos - "fluxos de capital, fluxos de informação, fluxos de tecnologia, fluxos de interação organizacional, fluxos de imagem, sons e 
símbolos" (CASTELLS, 1999, p. 501). Por isso, representam processos de dominação da vida econômica política e simbólica e se tornam "o suporte material dos processos dominantes em nossa sociedade será o conjunto de elementos que sustentam esses fluxos e propiciam a possibilidade material de sua articulação em tempo simultâneo" (CASTELLS, 1999, p. 501). Este espaço - de fluxos - “é a organização material das práticas sociais de tempo compartilhado que funcionam por meio de fluxos" (CASTELLS, 1999, p. 501).

Mas, é exatamente neste mesmo espaço que se pode vislumbra o retorno, ao lado das lutas reformistas - que dominaram o sindicalismo da segunda metade do século XX aos nossos dias - das lutas de caracteres político-revolucionárias, sem as quais não é possível o corte epistemológico para a eficácia da norma trabalhista no espaço, tal como propóem os autores deste trabalho, ou seja: do sistema de produção de normas internacionais - aplicáveis ou recepcionadas nos âmbitos locais e regionais; nos estados membros da União Europeia e do Mercosul - decorrentes de um pseudo consenso ou harmonia entre capital e trabalho, para criação e aplicação de normas provenientes de lutas coletivas - emancipatórias e contra-hegemônicas - a serem recepcionadas em níveis locais, regionais e supranacionais - deslocadas do trabalho livre/subordina, do sindicalismo reformista e voltadas para a prevalência da Economia Social e Solidária.

\subsection{A Redefinição Teórico-Dogmática da Eficácia da Norma Trabalhista no Espa- ço. As Ações Coletivas no Contexto dos Movimentos Sociais e das Teorias dos Movimentos Sociais}

No Direito do Trabalho, os movimentos coletivos partiam historicamente de uma vertente: os movimentos operários que se forjaram nas primeiras décadas do século XIX. Mas, o olhar da doutrina tradicional, sobretudo aquele que vem sendo lançado nos manuais, é quase sempre parcial e, por isso, peca pela superficialidade e repetição. É que ela concentra os seus argumentos nas lutas operárias que se desenvolveram no interior das organizaçóes produtivas e que foram responsáveis por conquistas efetivas, tais como: limitação da jornada de trabalho; fixação de uma remuneração mínima e os sistemas de garantia de emprego. Esqueceu-se, no entanto, do paradigma mais importante e sem o qual aquelas conquistas não teriam sido efetivadas - a luta política, emancipatória e contra- hegemônica.

A ação sindical - de tradição marxista ou anarquista - tinha plena consciência de que a classe burguesa se instituiu, como classe hegemônica, a partir do seu caráter universalista. Veio para ser hegemônica e impor o seu poder em todo o planeta, e náo em determinados estados ou regióes. A luta sindical se daria dentro destas duas perspectivas: a) aquela a ser travada no interior das organizaçóes produtivas e que teria uma conotaçáo meramente reivindicativa - esta, realçada pela doutrina jurídico-trabalhista -; b) a luta 
político-revolucionária dirigida à emancipação social e que deveria ser instituída desde os espaços locais e regionais até o espaço global - esta, negligenciada por aquela mesma doutrina.

A complexidade e as metamorfoses contemporâneas não eliminaram os paradigmas tradicionais vinculados aos movimentos sociais decorrentes do mundo do trabalho. Mas, por outro lado, quando o pesquisador se depara com a vasta bibliografia vinculada à teoria social crítica constata uma proposição que se torna uniforme, como pressuposto dos movimentos coletivos: a emancipação social.

Depara-se, pois, com proposiçóes e estratégias de lutas envolvendo questionamentos que vão além daqueles instituídos para combater as injustiças decorrentes da exploração do trabalho humano, forjadas no interior das organizaçóes produtivas - concepção reformista - e em dois sentidos: um combate específico contra a sociedade do trabalho centrada no trabalho subordinado, com o objetivo de permitir, nesta fase de transição, a hegemonia da chamada economia social ou solidária, a proteção de todas as alternativas de trabalho e renda compatíveis com a dignidade humana e a adoção de uma renda universal garantida. Diante das fragmentaçôes e metamorfoses vivenciadas, sobretudo a partir das rupturas introduzidas por meio da nova geopolítica global, promover o ajuntamento das lutas operárias a outras que vêm se desenvolvendo em torno deste núcleo comum - emancipaçáo social.

Implica, sobretudo, debruçar-se sobre uma análise específica, no que diz respeito às açóes coletivas e aos movimentos sociais, ou melhor, às Teorias dos Movimentos Sociais e seus paradigmas - seus paradigmas clássicos, contemporâneos e as possibilidades de sua reconstrução. Assim, ao contrário da visão reducionista de parte da doutrina jurídico-trabalhista, encarar as novas bases do protagonismo sindical contemporâneo, implica reconhecer que as açóes coletivas e os movimentos sociais devem estar envolvidos com o pensamento crítico .

Estas as razóes pelas quais vimos defendendo que os estudos direcionados aos movimentos e as açôes sindicais devem posicionar-se academicamente levando-se em conta as seguintes dimensóes: a) Remover as superficialidades encontradas em certos setores da doutrina dominante, no que se refere àquelas atuaçóes coletivas dirigidas ao interior das organizações, a fim de caracterizá-las a partir de sua memória histórica; b) Incluir as ações coletivas de natureza política, dirigida à emancipação social, para remover a subordinaçáo da força do trabalho ao capital; c) Articular os dois movimentos de natureza propriamente sindical aos demais movimentos libertários desencadeados atualmente, que têm a mesma natureza emancipatória e que se espalham por todo o planeta.

Foram os sentidos da universalidade e da fundamentação, da ideologia/hegemonia, do poder/saber, da estrutura - estruturada/estruturante - que legitimaram o trabalho 
subordinado como ethos da convivência das pessoas em sociedade e como a priori das teorizações do Direito do Trabalho. Daí não poder-se falar em emancipação social sem falar-se em lutas emancipatórias. Muito menos sem as lutas sociais historicamente desenvolvidas no âmbito das relaçóes coletivas de trabalho. Logo, este campo do direito não pode deixar de reconhecer o significado dos movimentos sociais na agenda da produção acadêmica nacional e estrangeira e, sobretudo, as teorias dos movimentos sociais.

Carlos Montaño e Maria Lúcia Duriguetto (2011) ampliam o universo teórico e político dos chamados Novos Movimentos Sociais. Por isso, apresentam uma divisão constituída de três grupos: o Grupo Acionalista; o Grupo da Esquerda Pós-moderna; o Grupo dos Segmentos Marxistas ou Comunistas.

As duas primeiras correntes "parecem hoje estar fundidas num rearranjo 'culturalista" (Idem, p. 330). Criticam também o enfoque institucional dos Movimentos Sociais, em que a atitude de confronto é deixada de lado, no sentido de privilegiar as condutas institucionais pragmáticas e propositivas que vão ao encontro do diálogo, da negociação e de formas alternativas de participação no sistema de representação de interesses. "Nesses espaços institucionais, bem como nos náo monopolizados ou controlados pelo estado, se buscaria reformular a noção de interesse público e a noção do 'direito a ter direitos'” (Idem, p. 334).

O grupo Acionalista, vinculado aos pensadores europeus não marxistas e influenciados pelos acontecimentos de maio de 68, na França - grupo liderado pelo sociólogo francês Alain Touraine, o alemão Tilman Evers, ao qual se integraria também a professora Maria da Glória Gohn. O segundo é constituído pela chamada Esquerda Pós-moderna e se inspira ainda nas teorias acionalistas. Também nega a herança tanto das bases teóricas marxistas - divisão da sociedade em classes; luta política revolucionária - quanto a vitalidade das organizaçóes clássicas (partidos e sindicatos), que estariam superadas exatamente em face das demandas dos novos movimentos sociais que, por sua vez, estáo centrados no universo cultural e na reprodução social - grupo em que se destaca o sociólogo Boaventura de Souza Santos. O terceiro reúne os Segmentos Marxistas e Comunistas, que se deslocam da dogmática stalinista e procuram enquadrar ou incorporar as demandas dos NMS às lutas de classe e às formas de organizaçáo herdadas do marxismo leninismo - partido e sindicatos - objetivando incorporar as lutas do NMS ao modo de produção capitalista e à luta política revolucionária. Concentra suas referências nas proposiçóes lançadas por Jean Lojkine e Manuel Castells.

Montaño e Duriguetto vinculam-se à Leitura Marxista sobre os "NMS", para afirmarem "o contexto histórico da análise marxista dos movimentos sociais dos anos 19601970 é exatamente o mesmo que o dos 'acionalistas'. A questão é que aspectos desse contexto são priorizados e como são interpretados; aí está o fundamento da divergência de análise" (Idem, p. 323). Antes, quando procuraram identificar "O aparecimento dos 
chamados 'NMS" (Idem, pp. 264-267), admitem que foi naquele período que eclodiu o aparecimento dos chamados Novos Movimentos Sociais, como o movimento mundial de protesto contra a guerra dos Estados Unidos no Vietná, o Maio de 1968, os movimentos ecológicos, urbanos antinucleares, feministas, dos homossexuais, pelos direitos civis dos negros nos Estados Unidos, entre outros (Idem, p. 264).

Reforçam os elementos positivos dessas novas alternativas de contestaçáo, de lutas e de insurgências. Reportam-se aos argumentos lançados por Bihr (1998) e destacam a entrada - na cena política - de temas voltados para questóes relativas "ao gênero, à raça, à etnia, à religiáo, à sexualidade, à ecologia, e aquelas que se relacionam à reproduçáo social, como os bens de consumo coletivo - saúde, educação, transporte, moradia etc." (Idem, 266).

O que diferencia as suas convicçóes das outras duas correntes é que, primeiro, tais movimentos revelam uma preocupaçáo maior e fundante: a reproduçáo do capital engloba um Modo de Produçáo Capitalista que, por seu turno, abarca a totalidade das condiçôes sociais de existência e as "condiçôes indiretas, secundárias, derivadas do movimento de apropriação capitalista da sociedade" (Idem, p 266). A compreensão marxista dos "NMS" coloca diretamente em questâo as relaçôes sociais capitalistas e as condiçôes imediatas de sua reprodução. Na medida em que os NMS náo se realizem no contexto e conjuntamente com a luta do proletariado (ou na ausência de uma luta como essa) deixa de lado um aspecto fundamental: a reapropriação das condiçôes sociais de existência. "A ausência de mediaçáo entre o movimento operário e os novos movimentos sociais desembocou na ausência de mediaçáo entre os próprios novos movimentos sociais entre si" (Idem, p. 267).

O segundo limite encontra-se vinculado ao particularismo de suas demandas e na tendência de cada uma delas se isolar "em um grupo de problemas específicos, frequentemente sem relação aparente de uns com os outros, favorecendo seu fechamento em práticas localizadas" (Idem, p. 266). Esta versão acaba por retirar desses movimentos a perspectiva de inserção na esfera de uma realidade estruturada - econômica, social e política maior e da luta de classes. "Essa 'retirada acabou por conduzir a uma convivência com o sistema, ainda que limitadamente contraditória, mas compatível com sua manutenção" (Idem, p. 266).

Para o pensamento marxista, a centralidade econômico-produtiva torna-se elemento fundante da "questão social". Logo, "suas manifestaçôes (pobreza, desemprego, questôes de gênero e ambiental, a xenofobia, discriminação racial, sexual etc.), não desvanecem com as significativas mudanças no mundo capitalista contemporâneo" (Idem, p. 324).

Referindo-se às ideias lançadas por Castells e Lojkine póem em relevo os seguintes argumentos: a) "os movimentos sociais como expressão das lutas de classes" (Idem, 
p. 325); b) a necessidade da formação de uma contra-hegemonia por parte das lutas de classes subalternas e a importância do partido político; c) o pensamento marxista acrescenta novos elementos no que diz respeito à articulação entre movimentos sociais e luta de classe, na medida em que esta luta não se limita à produção, mas envereda e envolve toda a sociedade e o aparelho estatal. Tem-se assim como uma síntese pertinente do pensamento lançado pelos citados professores:

Nesta perspectiva, Estado, sociedade civil e mercado (produtivo e comercial) são esferas da mesma realidade social e histórica, portanto, todas espaços de luta e demandas sociais, todas passíveis de conflitos e disputas. As ações sociais, e os movimentos sociais, podem se organizar em torno de demandas pontuais, e podem se desenvolver em espaços localizados, mas isso náo retira o fato, nessa perspectiva, de terem vinculação com a forma dada no sistema capitalista de produção e distribuiçáo de riqueza (fundado na relação de exploração entre as classes antagônicas, capital e trabalho) e seu acionar ter impactos (positivos ou negativos, transformadores ou mantenedores) das relaçóes e estruturas nas esferas estatal, mercantil e da sociedade civil (Idem, p. 324).

Saber se os NMS têm aspectos positivos ou negativos transformadores ou mantenedores da realidade social vigente implica identificar a prevalência dos aspectos positivos e transformadores da realidade social. Resumindo os aspectos relevantes traçados analiticamente por Mantaño e Duriguetto, é possível enumerar os seguintes: a) "A mobilização de massas e sua organização política estão intimamente ligadas no movimento revolucionário” (Idem, p. 329). b) “Em vez de 'parar' ou 'esfriar' quando confrontados ao Estado, o movimento social será definido, em última instância, por sua capacidade de transformar o sistema socioeconômico no qual surgiu” (Idem, p 329). c) O conteúdo ideológico e político das reivindicações e das ações devem definir "a capacidade de questionamento da hegemonia política da classe (ou fração de classe) dominante. Isso porque 'o alcance histórico de um movimento social pode ser definido pela análise de sua relação com o poder político" (Idem, p. 330). d) Sem desprezar a importância de uma luta simultânea de caráter reformista, ou buscar apreender as mediaçóes entre essas duas estratégias - reformistas e revolucionarias, Montaño e Duriguetto têm a clareza de que os movimentos sociais náo podem deixar de lado a luta pelos direitos em suas programáticas interventivas, mas advertem: "a ofensiva estratégia da luta pelos direitos, e pelas ideias de justiça e de equidade que os revestem, só adquire um sentido emancipatório se estiver em consonância, em sintonia, com a luta por um projeto de superação da ordem social vigente" (Idem, p. 351). O quadro que eles apresentam (Idem, p. 350) para descrever as características do Movimento Sindical, dos Novos Movimentos Sociais (NMS) e a Organização do Terceiro Setor sintetiza a composição analítica do seu pensamento. 
No âmbito da teoria social crítica e, mais particularmente, da cultura e do poder das organizaçóes, surge também um campo específico da psicologia que se encontra vinculado ao ativismo político que se volta para as representaçóes sociais em movimento e denuncia que temas relacionados à mobilização política são reduzidos a uma perspectiva ultrapassada e pessimista acerca das massas e das multidóes. Segundo Guareschi, Hernandez e Cárdenas (2010), ao se refletir criticamente acerca dessa “identidade negada”, é possível encontrar vários argumentos e intençóes ideológicas que justificam este posicionamento, tais como: "o enfoque individualista da psicologia dominante, a dualidade na constituição de uma Psicologia Política (ora individualista, ora comunitarista), a domestificação da vida pública proveniente, principalmente, da lógica individualista/capitalista” (Idem, p. 12).

Nenhum outro campo do direito se utilizou tanto da retórica para superação desses confrontos como o Direito do Trabalho, porque sempre esteve diante dos interlocutores sociais válidos - sindicatos obreiros e patronais, tanto para, por meio do processo não estatal - a negociação coletiva - produzirem, eles próprios, normas que sempre realimentaram incessantemente este subsistema jurídico ou para provocar os poderes instituídos - tanto nos espaços local, regional e supranacional - a resolver conflito e editar as regras a serem produzidas por esses mesmos poderes. Retórica que, no âmbito coletivo, se destina, como tantas vezes mencionado, à emancipação social.

Ver, dentro desta perspectiva, a eficácia da norma trabalhista no espaço, significa que ela não fica à espera - como sempre ficou - de uma visão do alto e de fora; uma visão que depende das organizaçóes internacionais; da maneira como elas pensam os sentidos de uma "cooperação internacional"; como se fosse possível um avanço neste campo do direito, que pudesse minimizar o impacto da assimetria entre os sujeitos desta relação jurídica especial - entre aquele que detém o poder de comando e aquele que submete a sua força de trabalho ao capital, sem a restauração das lutas emancipatórias que devem acontecer simultaneamente nos espaços locais, regionais e supranacionais.

\section{A Hermenêutica das Emergências e o Recurso à Reciprocidade. A Econo- mia Social e Solidária na Ibero-América}

Em 2005, Boaventura de Souza Santos (2005) coordenou uma obra que apareceu com o título Produzir para Viver: os caminhos da produção não capitalista. Aponta para uma hermenêutica da emergência e se propóe interpretar, de modo abrangente, a forma como determinadas organizaçóes, movimentos e comunidades resistem à força hegemônica do capitalismo e recepcionam alternativas econômicas baseadas em princípios não capitalistas.

Neste contexto, traça as diversas alternativas de economia autogestionária e reforça os seus fundamentos teóricos, as suas práticas e a importância em se disseminar a cultura da solidariedade, nesse momento de crise e de mudança de paradigmas. 
As investigaçóes pertinentes à economia social ou popular têm colocado em relevo a presença das entidades sindicais na formulação dessas alternativas. Em tempos de desemprego estrutural, de baixa filiação associativa, de sindicalismo reformista e de resultados, a presença da economia solidária nas organizaçóes sindicais amplia a sua capacidade discursiva e possibilita a adoção de novas estratégias de articulação e de lutas, em níveis locais e supranacionais.

Se, por outro lado, a proposta da doutrina trabalhista destina-se a ampliar os sentidos da proteção, para abraçar todas as possibilidades de trabalho e rendas e não apenas do trabalho subordinado, propomos, nessa esfera, a inclusão da Economia Social ou Solidária.

Se o que se busca é o recurso à reciprocidade, para dar sentido às relaçóes individuais de trabalho, ela também se apresenta como mecanismo de resistência dos trabalhadores às tendências atuais do capitalismo, para dar novo sentido às relaçóes sindicais.

As economias de autogestão são também denominadas de cooperativistas, economias informais ou economias populares. Seu conceito apareceu, pela primeira vez, no Brasil, em 1993, no livro Economia de solidariedade e organização popular, na qual o autor chileno Razeto a conceitua como:

uma formulação teórica de nível científico, elaborada a partir e para dar conta de conjuntos significativos de experiências econômicas [...] que compartilham alguns traços constitutivos e essenciais de solidariedade, mutualismo, cooperação e autogestão comunitária, que definem uma racionalidade especial, diferente de outras racionalidades econômicas (1993, p.40).

Nos dias atuais, define-se a economia social como sendo:

composta de organismos produtores de bens e serviços, colocados em condiçôes jurídicas diversas no seio das quais; porém, a participação dos homens resulta de sua livre-vontade, onde o poder não tem por origem a detenção do capital e onde a detençáo do capital não fundamenta a aplicação dos lucros (GUÉLIN, 1998, p.13).

Pode-se chamar de economia solidária, socioeconomia solidária, economia popular autogestionária e solidária, dentre outras. Por isso, se procura vivenciar um novo paradigma socioeconômico, político e cultural, com amparo na solidariedade, no qual esta última é vista como uma base essencial para a reconstrução do meio social nos quais vivem as classes populares ou de um novo modo de produçáo não capitalista.

Para Terezinha Libono, as principais características das empresas autogestionárias são:

controle totalmente exercido pelos trabalhadores; supressão da estrutura hierárquica de cargos, do parcelamento de tarefas, da desigualdade 
de vencimentos por tempo de trabalho, da separação entre concepção e execução, descentralização de decisões e participação direta dos agentes sociais implicados; valorização dos membros, proporcionando ambiente de segurança; o lucro deve servir ao desenvolvimento da empresa para que esta possa servir aos que nela trabalham bem como à coletividade; primazia das pessoas e do trabalho sobre o capital na distribuição de lucros (2007, p. 238).

Há, no cenário da Iberoamérica, um Mapa Alternativo de Produção ou de Economia Social e Solidária que prioriza a dignidade humana e a preservação do meio ambiente e da natureza. Nesta linha, que deve a mesma ser priorizada, inclusive, para impedir o avanço de um modelo de desenvolvimento destrutivo que vem comprometendo os nossos rios, as nossas florestas, com impactos desastrosos para o equilíbrio climático global.

Em resumo: essa alternativa hermenêutica procura também ampliar as esferas em que os intercâmbios estejam concentrados na reciprocidade e não nos ganhos monetários; desencadeie a diminuição da dependência das pessoas em relação ao trabalho assalariado; possibilita uma remuneraçáo igualitária dos trabalhadores-donos das empresas cooperativas, ao mesmo tempo em que cria formas de sociabilidade também solidárias, baseadas no trabalho colaborativo e na participação democrática na tomada de decisóes sobre as empresas.

Finalmente, procura reordenar ou redefinir a exploração crescente dos recursos naturais, em nível global, decorrente da competitividade, do modelo de produção e dos parâmetros de consumo instituídos nessa mesma dimensão que ameaçam esgotar esses mesmos recursos naturais e que têm permitido esse tipo desastroso de produção e de consumo.

As opçóes e propostas registradas pelo aludido sociólogo implicam reconhecer as possibilidades efetivas de novos modelos de desenvolvimento alternativos, ideias que já vêm sendo lançadas nas agendas dos institutos e cooperaçóes internacionais e ocupando um espaço relevante na produção acadêmica dos últimos anos. ${ }^{2}$

\section{Conclusões}

Embora o Direito do Trabalho se constitua como um ramo do conhecimento jurídico que surgiu da luta operária; que as relaçóes sindicais se sobreponham às relaçóes individuais fica patente a opção da doutrina pelo Direito Individual do Trabalho; opção

2 Apresenta um mapa exaustivo de alternativas de produção acrescido de dez estudos de caso que compóem o volume. Os estudos deixam ainda transparecer a importância da presença dos sindicatos na formação e no desenvolvimento das empresas autogestionárias, o que reforça a ideia de uma nova concepção para o Direito do Trabalho. 
que tem um impacto direto não somente na vida acadêmica, mas também na formação dos profissionais do direito vinculados a este campo do conhecimento jurídico.

Este perfil acadêmico repercute ainda e decisivamente na maneira de pensar o Direito do Trabalho. É como se ele fosse resultado de um consenso entre capital e trabalho, perfil ideológico cujo interesse é esconder a presença dos antagonismos de classes.

Para os autores deste estudo, embora o perfil assumido pela doutrina clássica tenha relevância para solucionar casos concretos ou pontuais; para dar sentido a uma harmonização de jurisprudência e resolver conflitos individuais puros ou individuais homogêneos e difusos; pouco importa, quando a matéria eficácia da norma trabalhista no espaço aparece dentre os pressupostos deste campo do direito. Logo, no contexto da Teoria Geral do Direito do Trabalho.

$\mathrm{O}$ que aqui se ressalta, por meio das teorias dos movimentos sociais e dos novos movimentos sociais, é a necessidade de insurgências trabalhistas a serem desencadeadas nos planos locais, regionais e supranacionais que possam estabelecer um confronto entre as orientaçóes normativas oriundas das organizaçóes internacionais ou cooperaçóes multilaterais; que o novo internacionalismo operário deixe de lado, como marco privilegiado, os movimentos reformistas e passem a assumir a ideia de que o as relaçóes de trabalho só podem seguir o seu destino histórico na medida em que assume, como premissa, o antagonismo de classe e não uma falsa harmonização entre capital e trabalho.

O tema eficácia da norma trabalhista no espaço ingressa aqui dentre aqueles que se inserem no contexto da Teoria do Conhecimento Jurídico-trabalhista e, a partir de uma nova pauta hermenêutica e de outros fundamentos teórico-filosóficos que procuram redefinir os fundamentos do Direito do Trabalho, levando-se em consideraçáo três argumentos centrais:

a) a redefinição do seu objeto - do trabalho livre/subordinado, para todas as possibilidades e alternativas de trabalho e rendas compatíveis com a dignidade humana, especialmente, a prevalência da Economia Social e Solidária como alternativa prioritária para Ibero-América.

b) a prevalência do sindicalismo revolucionário sobre o sindicalismo reformista;

c) o confronto entre a universalização/legitimação fruto da aliança entre filósofos e legisladores modernos e a universalização/legitimação que virá dos movimentos sindicais emancipatórios, poderá descolar o objeto do Direito do Trabalho e colocar, como a priori de suas teorizaçóes e objeto deste campo do direito, o trabalho livre e decorrente da Economia Social e Solidária, com impactos significativos para a Ibero-América. 


\section{Referencias}

ALTHUSSER, Louis. A Transformação da Filosofia. Seguido de Marx e Lênin perante Hegel. São Paulo: Ediçôes Mandacaru, 1989.

ANDRADE, Everaldo Gaspar Lopes de. O Direito do Trabalho na Filosofia e na Teoria Social Crítica. Os sentidos do trabalho subordinado na Cultura e no poder das Organizaçóes. São Paulo: LTr, 2014.

BAUMAN, Zygmunt. Ética pós-moderna. São Paulo: Paulus, 1997.

BINDÉ, Jérôme. Para o apartheid urbano? In: MATSURA, Kolchiro (Org.). As Chaves do Século XXI. Lisboa: Instituto Piaget, 2000, 435-443.

D’ANGELO, Isabele de Moraes. A subordinação no Direito do Trabalho. Para ampliar os cânones da proteção, a partir da economia social e solidária, 2014.

- Ressignificação do Trabalho Subordinado como Objeto do Direito do Trabalho. Recife: Duc in Altum. Caderno de Direito. Faculdade Damas. Centro de Investigação em Perspectivas de Historicidade do Direito no Estado - CIHJUR, Vol. 6, n. 10 (2014) pp.

DÄUBLER, Wolfgang. Derecho del Trabajo. Madrid: Centro de Publicaciones Ministerio de Trabajo y Seguridad Social, 1994.

FEITOSA, Enoque. Forma Jurídica e Método Dialético: a crítica marxista ao Direito. In:

FREITAS, Lorena; FEITOSA, Enoque (Orgs). Marxismo, realismo e direitos humanos. João Pessoa: Editora Universitária da UFPE, 2012.

GOHN, Maria da Glória. Teorias dos Movimentos Sociais. Paradigmas Clássicos e Contemporâneos. São Paulo: Edições Loyola, 1997.

. História dos Movimentos Sociais. A construção dos movimentos e lutas sociais dos brasileiros. São Paulo: Ediçốes Loyola, 1995.

GUÉLIN, André. L’invention de l'économie sociale. Paris: Econômica, 1998.

HOBSBAWM, Eric. A Era do Capital - 1848-1875. São Paulo: Paz e Terra, 2009.

HUBERMAN, Leo. História da Riqueza do Homem, Rio de Janeiro: Editora Guanabara, 1986.

KASHIURA Jr. Celso Naoto. Sujeito do direito e capitalismo. São Paulo: Outras Expressóes; Dobra Universitário, 2014.

KOSELLECK, Reinhart. Crítica e Crise: uma contribuição à patogênese do mundo burguês. Rio de Janeiro: EDUERJ/Contratempo, 1999.

KROPOTKIN, Piotr. Palavras de um Revolucionário. São Paulo: Editora Imaginário, 2005. 
LIBONO, Maria Terezinha Loddi. Um estudo de caso de autogestão. In: MATIAS, Maria Cristina Moreno; ABIB, José Antônio, orgs. Sociedade em transformação: estudo das relaçóes entre trabalho, saúde e subjetividade. Londrina: Eduel, 2007.

MARICATO, Hermínia[...] [et al.] Cidades rebeldes: Passe Livre e as manifestaçóes que tomaram as ruas do Brasil. São Paulo: Boitempo, 2013.

MARX, Karl; ENGELS, Friedrich. Manifesto do Partido Comunista (1848). Porto Alegre: L\&PM, 2012.

MENDONÇA, Talita Rodrigues. A Eficácia das Normas Trabalhistas no Contexto da Doutrina Clássica: para uma reconfiguração teórico-dogmática em fade das relaçôes individuais e coletivas de trabalho supraestatais. Recife: Programa de Pós Graduação em Direito da Universidade Federal de Pernambuco. Dissertação de mestrado. Texto avulso, 2012.

MONTAÑO, Carlos; DURIQUETTO, Maria Lúcia. Estado, Classe e Movimento Social. São Paulo: Cortez Editora, 2011.

NABUCO, Ary. Hackerativismo. A guerra Instalada no mundo virtual. São Paulo: Revista Caros Amigos, ano XVI, n. 184, 2012.

PEREIRA, Maria Clara Bernardes. A Livre Circulação dos Trabalhadores no Âmbito da Comunidade Europeia e do Mercosul: para além da doutrina jurídico-trabalhista tradicional centrada no trabalho subordinado e no sindicalismo reformista. Recife: Programa de Pós-graduação em Direito da Universidade Federal de Pernambuco. Dissertação de Mestrado. Texto Avulso, 2012.1

POSTONE, Moishe. Tempo, Trabalho e Dominação Social. São Paulo: Boitempo, 2014.

RAZETO, L. In GADOTTI, Moacir e GUTIERREZ, Francisco orgs. Educação comunitária e economia popular. São Paulo: Cortez, 1993.

ROBLEDO, Miguel Colina; MARTÍNEZ, Juan M. Ramírez; FRANCO, Tomás Sala. Derecho Social Comunitario. Valência: Tirant ló Blanch, 1991.

SOUTO MAIOR, Jorge Luiz. Curso de Direito do Trabalho: teoria geral do direito do trabalho, vol. I, parte, I. São Paulo: LTr, 2011.

SANTOS, Boaventura Souza de. Produzir para viver: os caminhos da produção não capitalista. Rio de Janeiro: Civilização Brasileira, 2005.

VAKALOULIS, Michel. Antagonismo social e ação coletiva. In: LEHER, Roberto;

SETÚBAL, Mariana (orgs). Pensamento Crítico e Movimentos Sociais. Diálogos para uma nova práxis. São Paulo: Cortez, Guareschi, Hernandez e Cárdenas (2010). 